\title{
Technologies for Constructing Schemes of Territorial and Spatial Distribution of Productive Forces in the Region
}

\author{
Yana Bondareva \\ Department of Applied Economics \\ and Economic Security \\ Belgorod State National Research University \\ Belgorod, Russia \\ Bondareva ya@inbox.ru
}

\author{
Mikhail Kochergin \\ Independent Researcher \\ Belgorod State National Research University, \\ Belgorod, Russia \\ Bondareva_ya@inbox.ru
}

\begin{abstract}
At the present time in Russia theoretical and methodological provisions on the spatial development of regions, formation of perspective schemes of productive forces location are discussed. The article considers the problems of constructing schemes of productive forces location, analyses theoretical and methodological provisions of productive forces spatial location, including modern integrated understanding of the category "productive forces" content, interpretation of the concept "productive forces location", principles, factors and methods of productive forces location. An algorithm of methodology for constructing the schemes of territorial and spatial distribution and development of productive forces (PSD) in the region has been worked out, and proposals on forming the current and prospective schemes of productive forces distribution have been made. The study focuses on the distribution of productive forces in industrial clusters. Such research is the basis for the formation of regional socio-economic development strategies, cluster and industrial policies. A prospective scheme for the location and development of the productive forces of the territory is used in the development of a comprehensive program of social development and economic development of the region. The presence of "economic resources" makes it possible to more reasonably solve the problems of specifications and integrated development of the region, based on the historically established level of industry, agriculture, transport, the use of production assets, the skills of the population, the rate of investment growth.
\end{abstract}

Keywords-productive forces, distribution of productive forces, territorial and spatial distribution scheme, industrial cluster, technologies of distribution of productive forces.

\section{INTRODUCTION}

Today, the involvement and activity of regions in the transformation of the national economy is of great importance in addressing the issues related to this process. For the country's economy, the effective shift from raw material orientation to the development of knowledge-intensive industries is quite relevant.

One of the main areas of modernisation of the country's economy is the process of clustering, which, in turn, helps identify and form new industrial clusters with their own infrastructure. Industrial clusters become so-called points of growth and contribute to the rational allocation of production forces.

«The mechanism of identifying industrial clusters is methodologically based on identifying significant cluster groups in the developed industries of the region» [3, p. 72]. Thus, the construction of prospective schemes of distribution of productive forces in the region is relevant and has great potential. The interest in the issues under consideration is great on the part of public authorities, private investors and directly economic entities.

The rational allocation of resources is of great importance, which in turn contributes to balanced spatial development and creates conditions for effective work of the whole production sphere of the region.

In turn, localisation of actors of production activities can lead to a multipolar distribution of 'points of growth' in the region. Rational allocation of resources contributes to significant savings of production costs, increases efficiency, competitiveness of economic entities and the region as a whole. Fundamental research will be carried out on the following groups of problems: re-interpretation of the conceptual and terminological apparatus of the1 Soviet school of industrial-era location theory; analysis of new foreign location theories, empirical synthesis of studies by European and American scientists in this field in the last 25 years and3 determination of the adequacy of their proposed theoretical concepts, methodological approaches, methodological apparatus for Russian realities; assessment of the situation in the new geographical distribution of human resources, material, natural and intangible assets of Russia Determination of attraction and repulsion factors in the behaviour of investors when locating new/redeploying old firms and modelling of forecast location of new commercial enterprises in Russian regions; Mathematical modelling of environmental and climate change impacts on settlement shifts and firm location at a micro level in municipal 
formations and individual firms; Assessment of economic effects of efficient location of Russian productive forces (higher productivity, lower material and transactional costs, etc.).

\section{METHODS}

The following conclusions have been drawn by economists for the last centuries concerning the concentration and deformation of economic space around the growth poles. A huge role belongs to the theory of $\mathrm{M}$. Porter, who gave a complete substantiation of spatial development of territories. Development of the theory continued in the works of $\mathrm{M}$. Enright [9]. By the mid twentieth century, systems of new placement theories were being created. In the theoretical constructions of W. Kristaller [8], A. Lösch [12], E. Hoover [15], W. Izard [14], H. Bos [5]. The second paradigm of productive forces allocation is associated with this methodological principle. Our researchers were also engaged in studying the questions of productive forces location, among them I.G. Alexandrov, N.N. Kolosovsky, L.L. Nikitin, N. N. Baransky, G.N. Chetyrkin, P.M. Alampiev, Y. G. Feigin, N. N. N. Nekrasov, M.K. Bandman, M.D. Sharygin, the system of economic zoning of the country was created and practically implemented, acting as the most important part of theoretical and methodological research carried out for the purpose of rational distribution of productive forces [4]. «The considered questions of territorial and spatial distribution of productive forces do not lose their relevance today.

For today some moments in definition of the category "productive forces", and also in the mechanism of productive forces distribution itself are ambiguously perceived. The modern interpretation of productive forces concept emphasizes the people who have knowledge, production experience, skills to work and who actuate the set of means of production» [6]. It should be noted that the degree of influence of the factors of concentration of production forces is in constant dynamics, the structure and quantity of consumed resources are changing rapidly. The region's labour resources, their qualification potential, as the main element of the technological and innovative nature of production processes, come to the fore. The degree of development of the region's infrastructure, which includes economic zones, technology parks, technology transfer centres. Creation of new elements of spatial development of territories with the formation of world-class scientific and educational centres. In our opinion, the integration of the region's economy into the global economic space can influence the priorities of productive forces distribution.

In our opinion methodological basis of formation of schemes of distribution of productive forces consists of principles of rational spatial organization of territory, economic and social efficiency, rational combination of nature and economy. The composition of general methodological principles and methods does not differ significantly according to the proposals of different authors. The implementation of the highlighted principles and regularities is classically carried out by using a certain set of methods compiled taking into account regional factors of productive forces distribution.

Taking into account multifactorial character of modern regional economy and functional purpose of productive forces the definition of "productive forces" category was used. On the basis of the conducted analysis, in our opinion, the productive forces can be considered as the set of subjective and objective factors of production which interact between each other, in the process of which their functional purpose is realized through the growth of social and economic indicators on regional level, improvement of population life quality, development of infrastructural environment.

«The rational allocation of productive forces has a direct impact on the efficiency of production, allows a more efficient use of resource potential, can improve the environmental situation, and increase the profitability of economic entities. The implementation of this principle actively uses innovative technologies that allow a more rational use of limited financial, raw material and labour resources» [4].

The current geopolitical situation allows one to conclude that the efficient location of productive forces can also have a great influence on strengthening the defence capability of the country as a whole. As the scheme of distribution of productive forces can be formed depending on the purposes and tasks set by the authorities for solving these or those problems. Ensuring the creation and development of efficient production facilities close to sources of raw materials and energy, as well as to the place of consumption of finished products, is a serious and often impossible task. Further specialisation, which causes unevenness in the location of production facilities in certain areas, adds to the difficulty of solving this task. A clearer mechanism with specific tools is needed to eliminate the emerging problems, allowing for a more effective formation of schemes of territorial and spatial distribution of productive forces in the region. It is important to note that the effective regional development is associated with the territorial location and level of production and consumption of material goods. This statement is confirmed in practice, making it possible to use the experience of regions with high economic indicators in the formation of schemes of distribution of productive forces in new territories.

The following methods were used to form the schemes of territorial and spatial distribution of productive forces (PSF) in the region: statistical, program-targeted, method of economic and mathematical modeling, index and cartographic methods.

The result of using the cartographic method is a graphic map of the distribution of productive forces, made by types of selected industrial clusters.
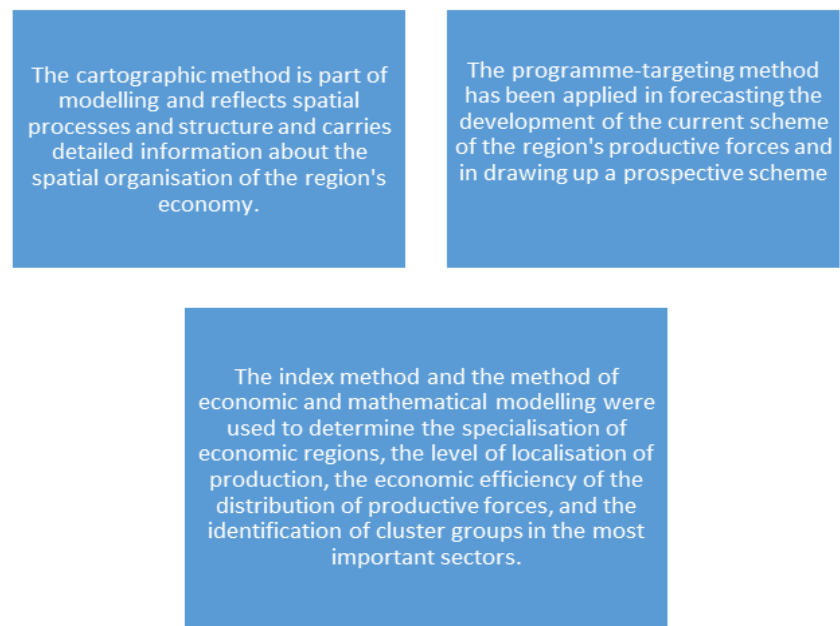

Fig.1. The main methods used to shape territorial spatial RPS schemes 
«It is important to identify the factors of production allocation, which are a set of conditions influencing the organization and allocation of productive forces in the region» [13]. «It is necessary to identify those factors that influence the distribution of productive forces out of the variety of groups. In our opinion, they can include infrastructural, economic and geographical position, natural-resource, transport, labor factor, territorial concentration, environmental factors. Economic infrastructure is one of the main factors of production allocation, allowing for agglomeration effect. Infrastructure as a category of the regional economy is a complex of service facilities, a set of structures, buildings, systems and services that are necessary for the normal functioning of production, as well as for the effective development and functioning of a particular territory» [13].

From the point of view of the cluster approach, infrastructure represents five subsystems that contribute to the effective accumulation and distribution of funds, and the provision of services for the development of technological transfer activities, commercialization of scientific and technological products (Figure 2):

Of all the variety of economic factors influencing the development and location of production, the logistics component, transport, acquires great importance. The totality of factors plays an important role in the distribution of productive forces. When considering the factors, it is necessary to take into account all the conditions under which the criterion of efficiency can be realised. Consideration of each factor is accompanied by analysis of its influence on the process of productive forces placement.
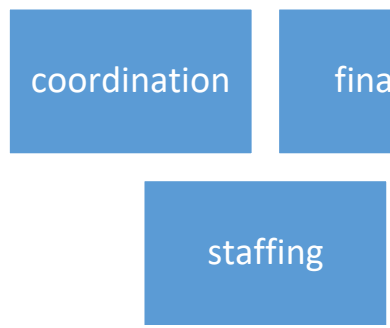

information

and advisory services

\section{Fig.2. Main infrastructure subsystems}

However, it should be noted that an isolated consideration of the role of individual factors of placement does not provide an overall picture, as it is necessary to take into account the influence of all placement factors at the same time.

\section{MAIN PART}

It should be noted that when assessing the potential of a region and developing its SWOT-analysis, special attention should be paid to the comprehensiveness of the regional economy and the assessment of structural shifts.

The substantiation of the main points of the schemes is made by means of the analysis of socio-economic situation of the certain territory, inventory of social, economic and natural-resources potential of the region. This is followed by the analysis of existing and forecasting probable contradictions in the process of social and economic development of the territory. The forecasts of natural resources and dynamics of their development, demographic forecasts, social forecasts, economic forecasts of production dynamics and its structural shifts, forecast assessments of the development of inter-sectoral complexes and national economy sectors, scientific and technical forecasts, etc. were used. Following this, it is necessary to formulate strategic objectives and priorities of development, as well as to work out the main elements of the regional mechanism for managing the development and distribution of productive forces in a particular territory.

Of all the models of regional development after a long analysis for implementation in a particular territory, in our opinion, the concept of polarized development is more attractive, because under the conditions of instability, characterized by the presence of a number of problematic and depressed industries and territories, a successful combination of intellectual, industrial, natural resource potential and a unique geographical location, and also given the acute lack of investment resources, the greatest economic and social effects.

\begin{tabular}{|c|c|c|}
\hline Name of stage & $\begin{array}{c}\text { Characteristics of } \\
\text { the stage }\end{array}$ & $\begin{array}{l}\text { The results } \\
\text { obtained }\end{array}$ \\
\hline $\begin{array}{l}\text { - Study of } \\
\text { theoretical } \\
\text { aspects of } \\
\text { territorial and } \\
\text { spatial } \\
\text { distribution of } \\
\text { productive } \\
\text { forces. } \\
\text { - } \\
\text { - Study of } \\
\text { territorial and } \\
\text { spatial } \\
\text { distribution of } \\
\text { productive } \\
\text { forces (PSF) } \\
\text { of the region. } \\
\text { - } \\
\text { - Study of the } \\
\text { institutional } \\
\text { and legal base } \\
\text { of territorial } \\
\text { and spatial } \\
\text { distribution of } \\
\text { productive } \\
\text { forces (PSF) } \\
\text { and provision } \\
\text { of the region's } \\
\text { clusters' } \\
\text { activity. } \\
\text { - } \\
\text { - Study of } \\
\text { territorial and } \\
\text { spatial } \\
\text { distribution of } \\
\text { productive } \\
\text { forces (PSF) in } \\
\text { the identified } \\
\text { industrial } \\
\text { clusters in the } \\
\text { region. }\end{array}$ & $\begin{array}{l}\text {-Definition of a } \\
\text { common framework } \\
\text { of concepts. } \\
\text { Definition of } \\
\text { concepts of PS, } \\
\text { RPS, methodology, } \\
\text { methods, principles, } \\
\text { etc. Drawing up a } \\
\text { list of PSD } \\
\text { principles. } \\
\text { Selection of PSD } \\
\text { factors. } \\
\text { - } \\
\text {-Analysis of the } \\
\text { region's place in the } \\
\text { economy of the } \\
\text { Russian Federation. } \\
\text { General } \\
\text { characteristics of } \\
\text { the socio-economic } \\
\text { position of the } \\
\text { region. } \\
\text {-Analysis of the } \\
\text { region's potential. } \\
\text { SWOT-analysis of } \\
\text { the region. } \\
\text { Compilation of the } \\
\text { scheme of the } \\
\text { region's PS } \\
\text { location. } \\
\text { Determination of } \\
\text { the priority } \\
\text { directions of the } \\
\text { region's } \\
\text { development. } \\
\text { - Analysis of the } \\
\text { existing legal and } \\
\text { regulatory } \\
\text { framework } \\
\text { governing the } \\
\text { issues of cluster } \\
\text { development in the } \\
\text { Russian Federation. } \\
\text { Analysis of the } \\
\text { existing regulatory } \\
\text { framework } \\
\text { governing the } \\
\text { issues of cluster } \\
\text { development in the } \\
\text { region. } \\
\text {-Analysis of } \\
\text { clusters in the } \\
\text { region. } \\
\text { Identification of the } \\
\text { composition of the } \\
\text { most promising } \\
\text { industrial clusters }\end{array}$ & $\begin{array}{l}\text { - The system of } \\
\text { concepts and } \\
\text { principles used } \\
\text { in the } \\
\text { development } \\
\text { of schemes of } \\
\text { territorial and } \\
\text { spatial } \\
\text { distribution of } \\
\text { productive } \\
\text { forces (PSF) } \\
\text { of a region. } \\
\text { - Assessment of } \\
\text { the region's } \\
\text { attractiveness } \\
\text { and } \\
\text { development } \\
\text { potential. The } \\
\text { list of } \\
\text { significant } \\
\text { sectors of } \\
\text { regional } \\
\text { economic } \\
\text { development. } \\
\text { Identification } \\
\text { of promising } \\
\text { clusters in the } \\
\text { region. }\end{array}$ \\
\hline
\end{tabular}

Fig.3. Methodology for constructing schemes of territorial and spatial distribution of productive forces (PSF) of a region

Almost all successful projects implemented in different countries in the framework of regional policy are in one way 
or another related to this concept, which implies the formation of all kinds of poles, centres, corridors and development areas. The classical orthodox concept of polarised development can be adapted to the conditions of a particular territory, based on the strategic interests, goals and development priorities of this region. Specific organisational forms of polarised development need to be developed, which allow to realise the main interests, goals and priorities with the greatest effect in practice.

The methodology of constructing schemes of spatial distribution of productive forces in the region can be used in the development of the RPS programme of a particular territory. The purpose of the RPS Programme is to determine the direction and ways to solve socio-economic problems of the region, effective use of resources, production specialization and the main parameters of economic complex development of the region, territorial alignment of the levels of social development of economic areas (municipal districts, urban districts), improvement of sectoral and territorial proportions of economic development.

The territorial and sectoral approaches should be synthesised in the development of the RPS Programme.

The RPS Programme is a long-term document and is developed for a long-term period. The first of the planned years is reflected in the RPS Programme on an annual basis, the subsequent ones in five-year intervals. The nature of the document implies periodic adjustments and adaptations to changing conditions. This requires regular monitoring of the situation, analysis of the data obtained and comparison with the forecasts of the RPS Programme. In this regard, a Situational Modelling Model shall be included in the Programme.

The elaboration of the PSD Programme by the following steps:

1. Development of the Macroeconomic Block (scenario conditions) of development and distribution of productive forces

The Macroeconomic Block includes an analysis of the state of the economy and the social sphere, a strategy of socioeconomic development of the territory's economy for a longterm period.

Based on the provisions of the Macroeconomic Block, sectoral Schemes of Development and Allocation of the Territory's Productive Forces with benchmarks for the following sectors, types of activities are developed:

- industry, with a breakdown by sector;

- agro-industrial complex

- transport complex and communication

- construction industry;

- material basis of the social sphere branches (health protection, education, culture and arts, social services, environment, employment, demography, migration)

- science and innovation;

- innovation infrastructure and technology transfer;

- interregional and foreign economic relations;

- logistics;
- ecology;

- small business;

- consumer market;

- concept of development of financial institutions.

Sectoral BPS Schemes are built on the basis of the development programmes of individual sectors, activities and priorities of economic policy in the context of options for scenario conditions.

Sectoral RPS Schemes should provide for variant forecasting of development trends, objectives, and specific mechanisms for their achievement. The rationale for the choice of option is made on the basis of estimated performance indicators.

Sectoral RPS Schemes are balanced by all types of resources (raw materials, production, financial, property, labour, energy, transport, information) and are specified if necessary.

Balance ratios of production of goods and services for the future allow to define the basic technical and economic indicators of territory development for the considered period taking into account the proposed schemes of distribution and development of productive forces.

3. The development of sectoral schemes of RPS in the context of municipal districts and urban districts.

4. Based on the results of balancing of sectoral RPS schemes, forecasts of socio-economic development of municipalities, territorial schemes by economic areas are developed: in the context of municipalities (urban districts, municipal districts, settlements) location of production of important products and production capacity (facilities), facilities of social sphere.

Territorial Schemes of RPS are re-balanced and refined if necessary.

5. The sectoral and territorial sections are linked in terms of clusters.

\section{CONCLUSION}

The scheme of productive forces distribution proposed by us is universal and can serve as a basis for elaboration of a complex program of socio-economic development of territories, taking into account their peculiarities of problems and perspective directions and spheres of activity.

It should be noted that the developed schemes allow to solve problems of specialization and comprehensive development of the economy of territories in more detail and with the best results. Institutional support of the proposed measures is a prerequisite for successful implementation of the methodology for the development of current and prospective schemes of productive forces allocation. The current scheme of distribution of productive forces is presented in the form of the following blocks: 


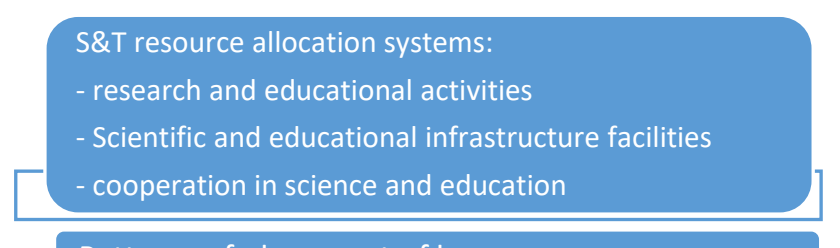

\section{Patterns of placement of human resources}

Schemes of the location of production and technical resources

Patterns of organisational development of the cluster

Fig.4. Current layout of productive forces

Proposals for the formation of a prospective scheme of productive forces deployment of identified regional clusters have the same structure. It is necessary to create working groups to address the issues of improving the system of distribution of productive forces and increasing the degree of homogeneity of socio-economic development of the municipalities that make up the regional agglomeration by maximizing their potential and advantages.

At the same time asymmetry in the spatial development of industrial production of territories, can have a negative impact on the socio-economic development of the region. In order to study in detail the potential of the territory it is necessary to use the principle of macrozonation. As a result, it is necessary to identify four types of macro-zones: with intensive type of industrial production, with potential, with problematic development of industrial production (traditional production on the old technological platform), zones of non-industrial production. The package of measures for each zone is designed to reanimate production. At the same time, emphasis should be placed on the supporting development territories, which are designed to synthesise innovative, technological, human and other innovations, and thus to involve in industrial turnover a variety of production sites.

Projects and placement of productive forces in the region, reflect the real state of affairs in the socio-economic life of the territory, can become the basis for long-term forecasting, provide answers to many questions related to the potential of this or that territory.

In the future, the draft schemes under consideration must be competently positioned, and this is a task not only for the developers but also for the authorities. Thus Federal Law N172 "On strategic planning in the Russian Federation" represents a major breakthrough in this matter.

The developed regional schemes, without contradicting either the Federal Law N172 or other laws, will make it possible to solve the issues of locating the productive forces on a certain territory. It would be advisable to position the scheme as a forecasting and analytical document, which is part of the strategy for the socio-economic development of the territory. When analyzing any successful region, we can conclude that this success is primarily achieved through effective interaction between the authorities, business, academia and civil society. The initiative to create a regional scheme of development and distribution of productive forces in the region is of great importance and clearly demonstrates the activation of public authorities in influencing the prospects of the region. The scheme itself allows us to see the

resource endowment. Each section identifies not only strengths, but also problem areas. However, even with this in mind, the way forward for the development of the productive forces of a particular area looks rather optimistic.

To describe the new economic geography as a new theory of location which has appeared in foreign regional science in the last 20 years. An analysis of the shifts that have occurred in the distribution of Russia's productive forces at the macro and micro levels over the past two decades is evident. Macrolevel spatial shifts are analyzed with the help of macro indicators and on the materials of investment activity in Russia. The micro-level is analysed on the basis of hundreds of investment projects, including both new and modernization projects in Russia. The impact of climate change on the location of Russia's productive forces must be considered using the specific example of climate and thermokarst processes in the area of intensive oil and gas development. The main conclusion of the first stage of the study is to form the notion that the emerging new reality in the location of productive forces in Russia is a reflection of global patterns inherent in all countries that are undergoing post-industrial transition, but in the vast spaces of Russia these patterns inevitably manifest themselves with certain specifics. The most important challenge is precisely to organically link global regularities and national specifics in the distribution of Russia's productive forces.

\section{ACKNOWLEDGMENT}

The research was carried out within the framework of the state assignment of NRU BelSU FZWG-2020-0016 (0624-2020-0016), the topic of the project "Fundamental foundations of global territorial and industry specialization in the context of digitalization and technology convergence".

\section{REFERENCES}

[1] M.V. Andreev, "Analysis of approaches to Assessment of cluster policy implementation", Modern Economics: Problems and Solutions, 2015, no. 7(67), pp. 100-107.

[2] M.V. Andreev, "Cluster as an integrative association of a group of economic entities with characteristic identification features", Problems and prospects of modern economics: collected works. Voronezh, VGPU, 2016, pp. 26-36.

[3] M.V. Andreev, A.E. Dmitriev, L.P. Pidoimo, Actual aspects of regional cluster policy in the industrial sector of the economy: monograph, Voronezh, Voronezh State University Publishing House, 2016.

[4] I. I. Belousov, Fundamentals of the doctrine of economic zoning. Distribution and zoning of production forces.Bases of knowledge about economic zoning. Location and zoning of productive forces, Moscow, Moscow State University, 1976, 320 p

[5] Kh. Bos, Placement of the farm, Economy location: translated from Russian,Moscow, Progress, 157 p.

[6] A.B. Borisov, Big dictionary of economics, Moscow, Knizhny Mir, 2003.

[7] V.K. Bugaev, Territorial structure of economic district, Leningrad, Nauka, 1986.

[8] W. Cristaller, The Central Places of Southern Germany, Englewood Cliffs, N. J.: Prentice-Hill, 1966.

[9] M.P. Voynarenko, Cluster technologies in the system of entrepreneurship development, integration and investment attraction". URL: https://tinyurl.com/y6x2kcmj (accessed 26.11.2020).

[10] E. Kovalenko, T. Polushkina, O. Yakimova, Y. Akimova, Regional economics and management: textbook, Saint Petersburg, Peter, 2018.

[11] E.S. Kutsenko, "Project Identification of the main directions for the development of clusters in the RF subjects: methodological note, Portal of subcontracting and cluster technology development. URL: http://www.promcluster.ru/images/UPLOAD/metodologia issledovania.pdf/(accessed 05.11.2020). 
[12] A. Lyosh, Spatial organization of the economy: per s nem. Economy spacial organization: translated from German, Moscow, 2007, 663 p.

[13] Y.A. Supereka, Economic geography and regionalistics. General characteristics of the North Caucasus economic region: Ph.Econ. Moscow, 2008. URL: https://tinyurl.com/y2lwaqe8/(accessed 25.11.2020).

[14] U. Izard, Methods of the regional analysis. Introduction in the science about regions, Moscow, Progress, 1966. $660 \mathrm{p}$.

[15] E. M. Hoover, The location of economic activity, New York, 1948, 310 $\mathrm{p}$ 